work when completed, and a glance at the first volume, although I have been unable to read it, suggests that it is more encyclopædic-mentioning almost everything that has been done.

"The Oceans" will appeal to many seafarers ; many ships would be glad to have a copy. There is no doubt that it will be very effective in promoting research, and increasing our knowledge of the oceans.

G. E. R. DEacon.

1 "Die absolute Topographie des physikalischen Meeresniveaus und die Oberflächenströmungen des Schwarzen Meeres". By
Neumann. Ann. Bydrog, und Mar. Meteorol., 70, ix (1942).

\section{BIRDS OF THE SOUTH-WEST PACIFIC}

Birds of the South-West Pacific

A Field Guide to the Birds of the Area between Samoa, New Caledonia and Micronesia. By Ernst Mayr. Pp. $\mathrm{xx}+316+3$ plates. (New York: The Macmillan Company, 1945.) 3.75 dollars.

A FTER the American Forces commenced operations among the Pacific Islands, the American Museum of Natural History was inundated with requests for a book on the birds of the region. There was, however, no work on the whole area published, although many papers had been written on the birds of the different groups of islands. Fortunately, a member of the staff had already made a special study of the species found in the Pacific and neighbouring areas. This was Dr. Ernst Mayr, and no one was more competent to write the present volume, since, in addition to his systematic studies, he has spent several years in New Guinea, the Bismarck Archipelago and the Solomon Islands, and accordingly was familiar with many species in the field. The area covered by this volume comprises the groups of islands from Tonga in the south to the Mariana Islands in the north, and west as far as the Solomons.

In the introduction the author gives lucid hints on how to identify birds; he points out that though there may still be a few undetermined species in the mountains of the Solomons or in New Ireland, there remains much to learn of the life-histories and habits of nearly every bird.

The volume is divided into two parts : a general survey of the species, and more detailed lists of those found in the different groups of islands. In the first part, the birds are divided into groups, the sea birds, shore-birds, and land-and freshwater-birds. Of the sea-birds, the terns are by far the most numerous and embrace thirteen different species, but only one gull, the Australian silver-billed gull, occurs in the area. On the other hand, the petrels, ranging in size from the wandering albatross to a Mother Carey's chicken, though much fewer in numbers, are represented by more than twice as many species. The other sea-birds are the frigate and tropic birds and the widely spread boobies. With the exception of the Australian stilt, all the shore-birds are migrants from the north. Several, including the common sandpiper, turnstone and sanderling, are familiar summer and winter visitors to the British Isles. The remaining section embraces a great diversity of types: cassowaries, grebes, ducks, hornbills, sunbirds, honey-eaters and others, as well as several introduced species, namely, the Indian myna, Malay turtle dove and red-browed waxbill.
The second part gives additional details of th land-and freshwater-birds inhabiting the differen groups of islands, and here the observer will discove how little is known of the habits of many species In some of the archipelagos certain birds, such a flycatchers, whistlers (Pachycephala), white-eyes anc honey-eaters, tend to vary and divide up into race on the different islands. Dr. Mayr does not go int details on this point, but gives just sufficient par ticulars to recognize the races. This area is the headquarters of the brilliantly coloured fruit pigeon which combine such a wonderful variety of tints and New Caledonia is the home of the flightless kagu, which is now in danger of extermination since it falls an easy prey to prowling native dogs. The gems of the parrot-world, the tiny pygmy parrots, no more than $3 \frac{1}{2}$ in. long, are found in the Solomons; they bore holes in the nests of tree-haunting termites where they deposit their eggs. They are reported to feed on their hosts or possibly fungi.

There is a map on the inside of the cover, three coloured plates and sixteen line drawings which will facilitate the naming of species.

Dr. Mayr is to be congratulated on the production of this small work at such short notice, and there is no doubt it will be welcomed by the troops in the Pacific.

\section{ELEMENTARY ZOOLOGY}

A Manual of Elementary Zoology

By Dr. L. A. Borradaile. (Oxford Medical Publications.) Eleventh edition. Pp. xiii +813 . (London, New York and Toronto: Oxford University Press, 1945.) 24s. net.

THE first edition of "Borradaile" appeared in 1912 and the second only in 1918. The slow start was no doubt due to the first World War ; it is interesting to compare the book's record in the second. At some time in 1939 there was a second impression of the ninth edition, then came the tenth edition in 1941, its second impression in 1943, and now the eleventh edition in 1945. One wonders how many students this very valuable book has helped through the bewilderment of their first contact with zoological facts and ideas, and how many professional zoologists it has extricated from class-room and other difficulties. The publishers do not announce their sales, but they must now be very many thousands.

The new edition continues the book's development. There is increased attention to problems of function, reducing the force of the criticism made by some that the book devotes to these subjects less attention than is due even in an elementary text. In addition, there are some important changes in the chapter of embryology, where the development of Amphioxus is now based on Conklin's description. The account of gastrulation in the chick is the classical story of delamination, but more recent views are mentioned. The sections on genetics are somewhat expanded, with some discussion of mutation and recombination, and there are new diagrams of meiosis and crossing over. A new passage which should stir the interest of any intelligent student is that on the "History of the Vertebrata" in Chapter 22. Altogether, there are some fifty new figures.

The value of the book is proved by the number of its editions and reprintings; it is to be hoped that many more lie in the future.

P. D. F. Murray. 